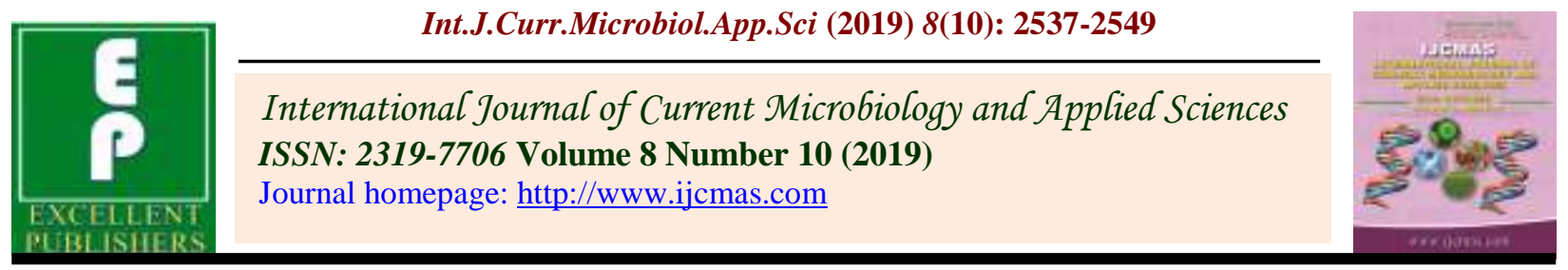

Original Research Article

https://doi.org/10.20546/ijcmas.2019.810.294

\title{
Comparative Study on Functional Characteristics of Whole and Gutted Pink Perch (Nemipterus japonicus) During Ice Storage
}

\author{
N. S. Sarve*, S. B. Patange, S. T. Sharangdher, J. M. Koliand and G. N. Kulkarni \\ Department of Fish Processing Technology and Microbiology, College of Fisheries, \\ Shirgaon, Ratnagiri, India \\ *Corresponding author
}

\section{A B S T R A C T}

\section{Keywords}

Whole, Gutted, Pink perch, Formaldehyde, Protein solubility, Gel strength.

Article Info

Accepted:

17 August 2019 Available Online:

10 September 2019
The present study was carried out to evaluate changes in biochemical, sensory and functional characteristics of whole and gutted pink perch (Nemipterus japonicus) during ice storage. Samples were drawn daily till the fish was organoleptically unacceptable. Organoleptic scores of ice stored pink perch ( $N$. japonicus) decreased gradually on 13 and 15 days respectively and it was acceptable. On 15 and 19 days there was ammonical odour and it was fully spoiled on $17^{\text {th }}$ and $21^{\text {th }}$ day of ice storage. Results of this study indicate that the shelf-life of whole and gutted pink perch stored in ice as determined by sensory scores is 13 and 15 days, respectively. The chemical indicators of spoilage, viz., trimethylamine and total volatile basic nitrogen values of gutted pink perch increased slowly, whereas for whole fish samples higher values were obtained reaching a final value of 17.08$12.04 \mathrm{mg}-\mathrm{N} / 100 \mathrm{~g}$ and $37.71-32.20 \mathrm{mg}-\mathrm{N} / 100 \mathrm{~g}$, respectively (17 and 21 days). The results showed a gradual decrease of $\mathrm{pH}$ values during the storage time. Heading and gutting prior to ice storage, retarted formaldehyde formation. Functional properties, showed decrease in protein solubility, gel strength, whiteness, water holding capacity, while increase in cook loss and expressible moisture content. Whiteness of surimi gel from gutted fish was much higher than that from whole fish, when the storage time increased. The gel strength of gutted fish found to be less as compared to whole fish, but the values of whole fish decreased rapidly as compared to gutted fish during storage. Determination of protein solubility, gel strength, water holding capacity, cook loss are useful in the assessment of changes occurring in proteins during ice storage. Significant correlations $(\mathrm{p}<0.05)$ existed among various functional properties of fish protein analysed with texture quality, in both the fishes during ice storage period. Therefore, storage time and pretreatment were found to be crucial factors, determining the changes in biochemical and functional properties of pink perch during ice storage. Instrumental texture attribute showed a strong correlation with gel strength of the pink perch surimi as storage period increased. 


\section{Introduction}

India has a long coastline of about $8118 \mathrm{Km}$ and an exclusive economic zone (EEZ) of approximately 2.02 million square kilometers. Fishing industries occupy an important position and they fetch considerable economic returns to the nation and provide employment opportunities. The fisheries sector is an instrument of livelihood for a large section of economically backward population of the country. More than 7 million fisher in the country depend on capture fisheries and aquaculture for their livelihood. Indian fisheries are an important contributor the global fisheries, India being fourth largest producer of fish in the world and second in inland fish production (Ayyappan, 2011).

The threadfin breams also called pink perch constitute an important demersal finfish resource in the Indian EEZ. These fishes are abundant beyond $50 \mathrm{~m}$ but show higher concentration at 100-200 $\mathrm{m}$ depth (Ayyappan, 2006). The threadfin bream is the most dominant among all the fish species landed along the Ratnagiri coast. In spite of the fact that nemipterids are mostly consumed in fresh condition, they have incredible values in the fish processing industry for fish sausage and fishery byproducts (Kumar et al., 2011). World interest for surimi continues to grow due to its unique textural properties and high nutritional benefit (Eymard et al., 2005). The decreasing supply of white flesh fish, such as Alaska Pollock, as the raw material for surimi has led to a new trend in surimi manufacturing (Tina et al., 2010).

The most important objective in postharvest technology of fish is to preserve its freshness. Many tropical fishes have longer shelf life when stored in ice than those from temperate water because of low number of psychotrophs (Disney et al., 1971). The storage life of marine fish in ice varies between 9 and 21 days (Bramstedt, 1965). According to Boyd and Wilson (1978), for every hour fishes held on deck at temperature between 14 and $18^{\circ} \mathrm{C}$, lose the equivalent of one day shelf life in ice. However, the rate of deterioration differs in different species. It is therefore, necessary to establish the freshness criteria for each species.

Freshness is considered as the most important factor determining the final gel quality. Gelforming ability is a very important indication of functional and textural properties of fish muscle (Benjakul et al., 2003). During handling, leakage of digestive enzymes into the muscle is found in subsequent hydrolysis of muscle proteins. Therefore, pretreatment of fish, including beheading and evisceration before handling, can be different means to retard the spoilage caused by proteolysis (Benjakul et al., 2002). Fish muscle lipid oxidation may be the initial factor for limiting storage life, causing the formation of unpleasant flavours and leading to the denaturation of proteins and decreased gelling ability through peroxide formation (Lanier, 2000). Whole fishes are often transported to surimi processing facility in iced condition either in the whole or gutted form. In certain instances, the duration of transportation varies from three to five days till the fresh raw material of whole or gutted fishes reached the surimi processing plant. Usually organoleptic attributes, the texture characteristics in particular are often evaluated for the acceptance of raw fish for surimi processing. There are no reports published with regard to sensory characteristics as also the texture of ice stored fish correlated with functional characteristics, especially the gel strength of the surimi prepared from pink perch.

Proteins are functional components in processed food, where they contribute to texture and sensory characteristics besides the 
nutritional properties. The myofibrillar proteins, contributing to $55-65 \%$ of total protein are the important protein fraction responsible for the physico-chemical properties of the protein in a food system (Lanier, 1986). Degradation of muscle protein is a major problem associated with fish during storage (Reddy and Sirkar, 1991a). Protein denaturation involves the formation of intermolecular aggregates through hydrogen, hydrophobic and disulfide bonds making denaturation an irreversible process (Connell, 1960). Post-harvest changes in fish muscle affect the quality of protein and hence its functional properties (Benjakul et al., 2003).

\section{Materials and Methods}

Fresh Pink perch (Nemipterusjaponicus) was kept in insulated box with flake ice in 1:1 (w/w) ratio (ice: fish) and brought to the College of Fisheries, Ratnagiri within 10-15 min of purchase. The whole fishes (W) were washed thoroughly and packed with ice: fish in alternate layers in the insulated box and stored under the chilled condition. In second lot, the fishes were subjected to semiprocessed $(\mathrm{G})$ with inclined cut dressing style and the further stored under the chilled condition. The sample was drawn daily till the fish was spoiled until 21 days and subjected to following biochemical, sensory and functional characteristics.

The TMA-N and TVB-N contents of fish sample were determined by micro diffusion method of Conway (Beatty and Gibbons, 1936).About $5 \mathrm{~g}$ sample was ground with 45 $\mathrm{ml}$ distilled water and filtered using a filter paper. The $\mathrm{pH}$ of filtrate was recorded using a $\mathrm{pH}$ meter (AOAC, 2005). The formaldehyde (FA) content of fish meat was determined according to Jaman et al., (2015). Organoleptic evaluation of iced fish was carried out as per the method of Burgess et al., (1965). The various characteristics of skin, eyes, gills, odour, colour, slime and texture were measured. Texture analysis was carried out according to Manju et al., (2007). The fish sample was filleted, and the centre part of the fish muscle was cut into uniform sizes $\left(2 \mathrm{~cm}^{3}\right)$ with skin and used for analysing the texture. The texture measurement was composed of two consecutive $40 \%$ compression of the sample at a crosshead speed $12 \mathrm{~mm} / \mathrm{min}$ using the texture analyser equipped with a cylindrical plunger (diameter $20 \mathrm{~mm}$ ). Protein solubility (PS) was determined using method of Choi and Park (2002). The gel strength and whiteness of surimi gel was measured according to Benjakul et al., (2003). Expressible moisture content, cook loss and water holding capacity were determined by the methods of Rewdkuen et al., (2009), Borresen (1980) and Nopianti et al., (2012).

\section{Results and Discussion}

TMA-N is a component of the total volatile bases (TVB-N) found in small quantities in fresh fish, increasing with time of storage. TVB-N Changes in TMA-N and TVB-N content of pink perch during ice storage are shown in Figure 1. The values of TMA-N and TVB-N increase as the storage time increase $(\mathrm{p}<0.05)$. On $17^{\text {th }}$ and $21^{\text {st }}$ day of storage period, TMA-N and TVB-N contents of gutted samples were generally lower than those of whole fish $(\mathrm{p}<0.05)$. Initially TVB-N content of whole and gutted samples was found to be 2.71 and $2.15 \mathrm{mg}-\mathrm{N} / 100 \mathrm{~g}$ and TMA-N content of whole and gutted samples was 0.75 and $1.03 \mathrm{mg}-\mathrm{N} / 100 \mathrm{~g}$ respectively. At the end of the ice storage period on $17^{\text {th }}$ and $21^{\text {st }}$ day TMA-N content of whole samples was approximately 1.2-1.5 fold higher than that of gutted samples. Both TMA-N and TVB-N contents in the whole samples increase at a higher rate than those of the gutted samples. At the end of experiment on $17^{\text {th }}$ and $21^{\text {st }}$ day, TVB-N content of whole and gutted samples was 37.71 and $32.20 \mathrm{mg}$ - 
N/100 g and TMA-N content of whole and gutted samples was 17.08 and $12.04 \mathrm{mg}$ $\mathrm{N} / 100 \mathrm{~g}$, respectively. Viscera and gills are the major sources of enzymes, as well as microorganisms. Accordingly, the removal of these organs presumably resulted in lower hydrolysis of the nitrogenous compounds. The formation of TMA-N and TVB-N is generally associated with the growth of microorganisms and can be utilized as an indicator of spoilage. Increase in the values of TMA-N and TVB-N are mainly attributed to the formation of specific spoilage bacteria such as Shewanella putrefaciens, Photobacterium phosphoreum, and Vibrionaceae, typically use TMAO as an electron acceptor in anaerobic respiration, resulting in off-odour and off-flavour due to the formation of TMA (Gram and Huss, 1996; Huss, 1995). The TVB and TMA formed in fish during iced storage were probably mediated by psychrotropic bacteria (Sasajima, 1973, 1975). The results suggest that pretreatment of pink perch by heading and gutting effectively retarded the spoilage during iced storage up to 21 days. These values are in the range of acceptable limit set for fish (Connell, 1975). The increasing value obtained for TMA-N and TVB-N was comparable with the increasing TMA-N and TVB-N as reported by Amitha et al., (2018) for iced storage of threadfin bream (Nemipterus japonicus). Similar reports of changes in TMA-N and TVB-N were observed by Cakli et al., (2007) for whole ungutted sea bream (Sparus aurata) and sea bass (Dicentrarchus labrax) stored in ice. Benjakul et al., (2003) also reported a significant increase in TMA-N and TVB-N of whole and gutted lizardfish (Saurida tumbil) during post-mortem storage in ice. Benjakul et al., (2002) also found an increase in TMA$\mathrm{N}$ and TVB-N values from whole fish and beheaded/eviscerated fish of big eye snapper, Priacanthus tayenus and P. macracanthus, stored in ice. Mehta et al., (2015) also reported an increase in TVB-N values from Catla catla, Labeo rohita and Cirrhinus mrigala during ice storage.

At the beginning of the storage, $\mathrm{pH}$ values of whole and gutted pink perch were determined as 7.45 and 7.3 respectively. The values decreased $(p<0.05)$ upon storage. At the end of the storage period, on $17^{\text {th }}$ and $21^{\text {st }}$ day, $\mathrm{pH}$ decrease to 5.44 and 6.2 respectively. Whole fish exhibited a faster rate of decrease in $\mathrm{pH}$ value than gutted samples. This is likely due to the fact that the aggregation of lactic acid in the muscle followed by break down of glycogen, the major energy source, through anaerobic pathway prompts to the accumulation of lactic acid. The changes in $\mathrm{pH}$ also depend on the liberation of inorganic phosphate and ammonium due to the enzymatic degradation of ATP (Viji et al., 2014). $\mathrm{pH}$ is considered as one of the most influential parameters in muscle protein functionality (Ofstad et al., 1995). Similar results of changes in $\mathrm{pH}$ were observed by Cakli et al., (2007) for whole ungutted sea bream (Sparusaurata) and sea bass (Dicentrarchuslabrax) stored in ice. Mehta et al., (2015) also reported such observations for Catlacatla and Labeorohita.

It was found that formaldehyde content increased persistently as the storage period increased $(\mathrm{P}<0.05)$. However, formaldehyde formation in whole samples was approximately two-fold higher than that of gutted samples (Fig. 2) on $17^{\text {th }}$ day of ice storage. The outcome exhibited that gutting had a prominent effect on the formaldehyde development in pink perch. At the beginning of the storage, formaldehyde content of whole and gutted pink perch was found to be 1.43 and $0.48 \mathrm{ppm}$ respectively. At the end of the storage period, on $17^{\text {th }}$ and $21^{\text {st }}$ day, formaldehyde increased to 9.99 and $4.51 \mathrm{ppm}$ respectively. Formaldehyde is formed by demethylation of TMAO, a compound 
present in most marine species. The formation of formaldehyde was clear in pink perch, indicating that pink perch had high contents of both TMAO and TMAO demethylase. During ice storage trimethylamine-N-oxide demethylase (TMAOase) is capable of catalysing the conversion of trimethylamine oxide (TMAO) to dimethylamine (DMA) and formaldehyde (Leelapongwattana et al., 2005). Formaldehyde bound with proteins was more likely involved in the aggregation of protein, resulting in the insolubilisation, and the changes in conformational and functional properties (Benjakul et al., 2004). It was seen that gutted fish contained much lower levels of formaldehyde. Visceral organs are known to be the most dynamic in the formation of formaldehyde. Harada (1975) has reported that the enzymatic formation of DMA and formaldehyde in the fish muscle, viscera and liver. In the initial days of storage the formaldehyde content in whole fish was increased slowly, after $14^{\text {th }}$ day formaldehyde content increased at faster rate till fish spoiled. In the case of gutted fish formaldehyde content increased slowly. Subsequently, the formation of formaldehyde in pink perch stored in ice is retarded by removal of gut content. However, formaldehyde was still formed at a lower rate in the muscle. Thus, gutting may retain the functionality of muscle protein, especially the gelation property, during the prolonged iced storage. Similar trends of changes in formaldehyde were observed by Benjakul et al., (2003) in whole and beheaded/eviscerated lizardfish (Sauridatumbil) during postmortem storage in ice. Chanarat and Benjakul (2013) also reported the same observations of formaldehyde on protein cross-linking and gel forming ability of surimi from lizardfish.

The organoleptic quality of whole and gutted pink perch (Nemipterus japonicus) during ice storage showed a decreasing trend in the scores for all attributes (Fig. 3) of fish, till it spoiled on the $17^{\text {th }}$ and $21^{\text {st }}$ day of ice storage. Pink perch initially had the following characteristics i.e., (a) skin: bright, shiny, no bruises, (b) eyes: condition of eyes crystal clear, convex black pupil, translucent cornea, (c) gills: bright red, (d) odour: fresh seaweedy, (e) colour: very bright and (f) texture: firm elastic to finger touch. The overall score was 9.1 and 9.2, the corresponding description belonged to "excellent" condition.

At the end of $15^{\text {th }}$ and $19^{\text {th }}$ day overall score for all attributes was found to be 3.2 and 3.6, i.e., assigned to grade III i.e., "poor" condition and had the following characteristics, i.e., (a) Skin: slight bruises, dull, (b) eyes: eyes was sunken, silky white pupil, opaque cornea, (c) gills: pale yellowish red, (d) odour: slightly ammonical odour, (e) colour: dull and (f) texture: soft. Similarly the changes in the organoleptic quality of whole and gutted pink perch in ice stored condition are correlated with the changes in texture of meat $(r=0.99, r=0.98)$, also change in organoleptic quality of whole and gutted pink perch in ice stored condition, inversely correlated with changes in trimethylaminenitrogen $(\mathrm{r}=-0.99, \mathrm{r}=-0.97)$ and total volatile bases- nitrogen $(r=-0.99 ; r=-0.98)$ respectively. Similar trends of changes in organoleptic characteristics was observed by Erkan and Ozden (2008) in whole and gutted sardines (Sardina pilchardus) stored in ice. Papadopoulos et al., (2003) also reported the same observations of organoleptic characteristics of sea bass (Dicentrarchus labrax) stored in ice.

Hardness 1 and Hardness 2 were found to decrease significantly $(\mathrm{p}<0.05)$ in both whole and gutted pink perch during ice storage. Hardness 1, decreased from the initial 779 to 257 g.cm and 436 on initial day to 247 g.cm of whole and gutted pink perch at the end of $17^{\text {th }}$ and $21^{\text {st }}$ day of ice storage respectively (Fig. 4). 
Fig.1 Changes in TMA-N and TVB-N content of whole and gutted pink perch during ice storage

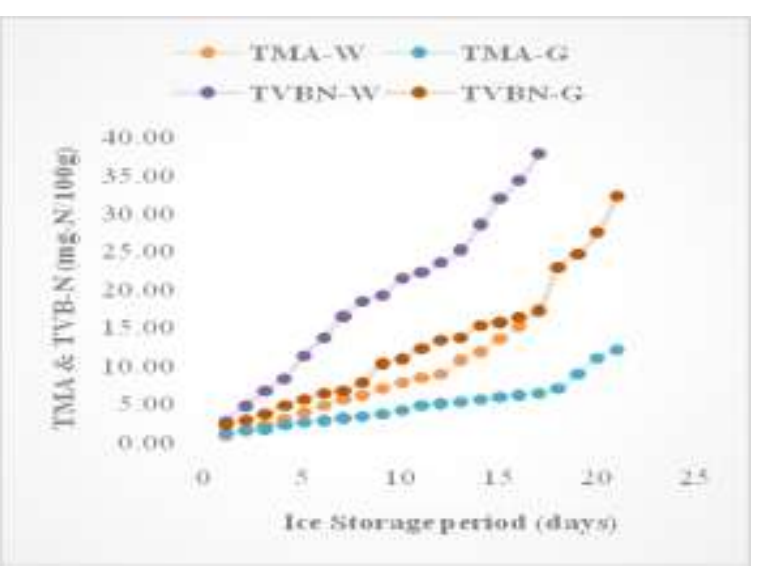

Fig.2 Changes in formaldehyde content of whole and gutted pink perch during ice storage

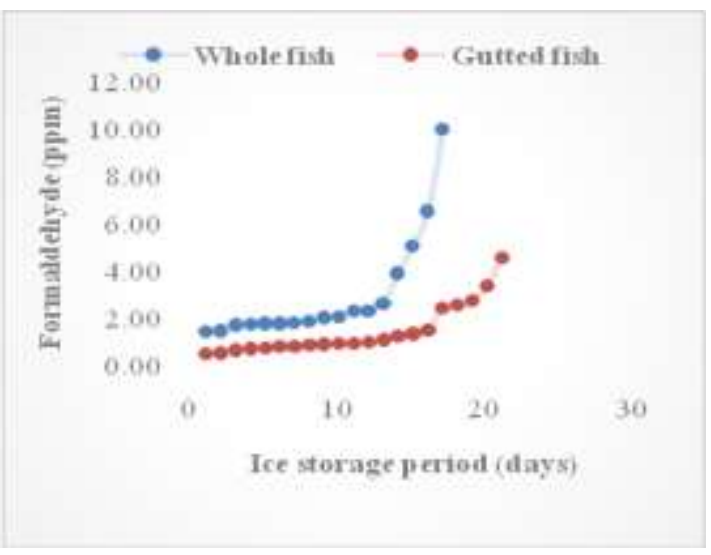

Fig.3 Changes in organoleptic quality of whole and gutted pink perch during ice storage

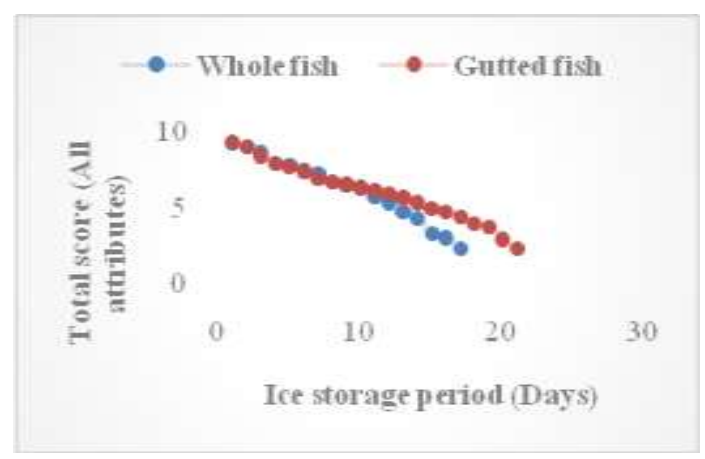

Fig.4 Changes in texture of whole and gutted pink perch during ice storage

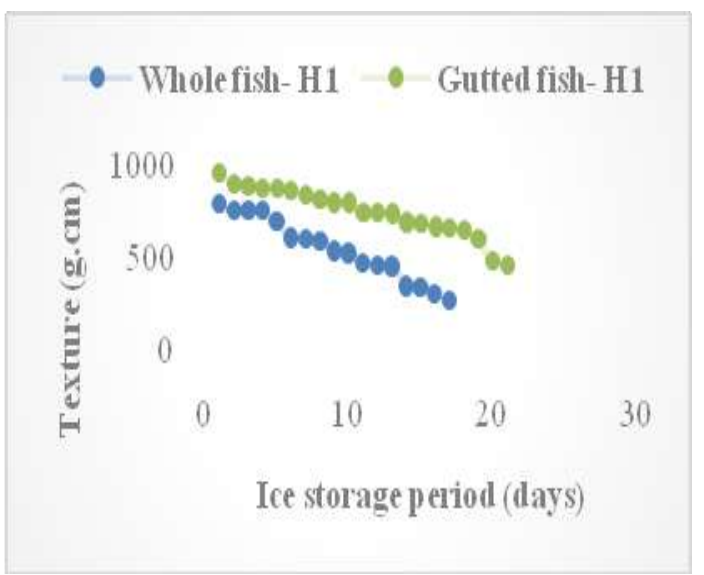

Fig.5 Changes in protein solubility of whole and gutted pink perch during ice storage

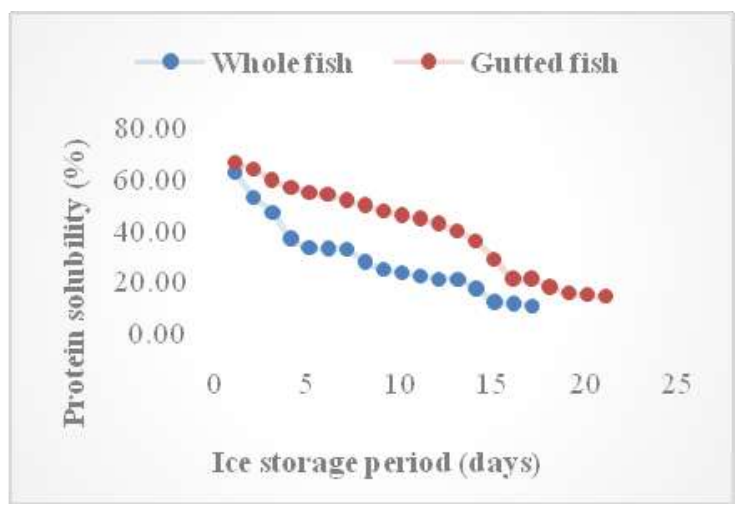

Fig. 6 Changes in gel strength of whole and gutted pink perch during ice storage

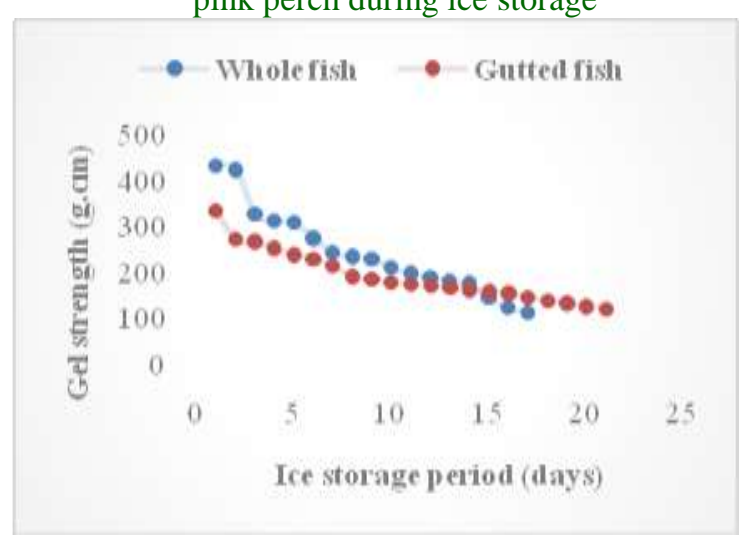


Fig.7 Changes in whiteness of whole and gutted pink perch during ice storage

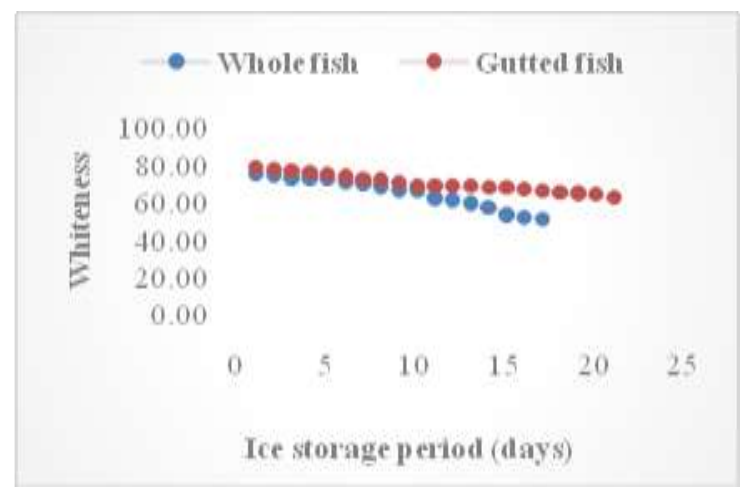

Fig.8 Changes in cook loss of whole and gutted pink perch during ice storage

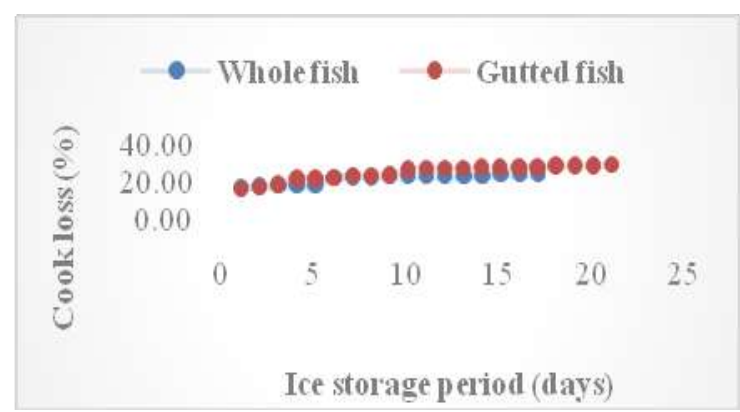

Hardness 2, decreased from the initial 944 to 449 g.cm and 823 to 445 g.cm of whole and gutted pink perch during ice storage respectively.

Hardness 1 and Hardness 2 continuously decreased as the storage period increased. Reduction in Hardness 1 and Hardness 2 values could be due to the weakening of connective tissue of fish muscle during storage, on account of the proteolysis caused by endogenous and microbial enzymes. The results of the present study are in agreement with those observed by Manju et al., (2007) who studied the effect of sodium acetate dip treatment on the shelf life of pearl spot (Etroplus suratensis). Hatae et al., (1985) also reported softening of the texture in several fish species stored at $4^{0} \mathrm{C}$ for up to 14 days. Viji et
Fig.9 Changes in expressible moisture content of whole and gutted pink perch during ice storage

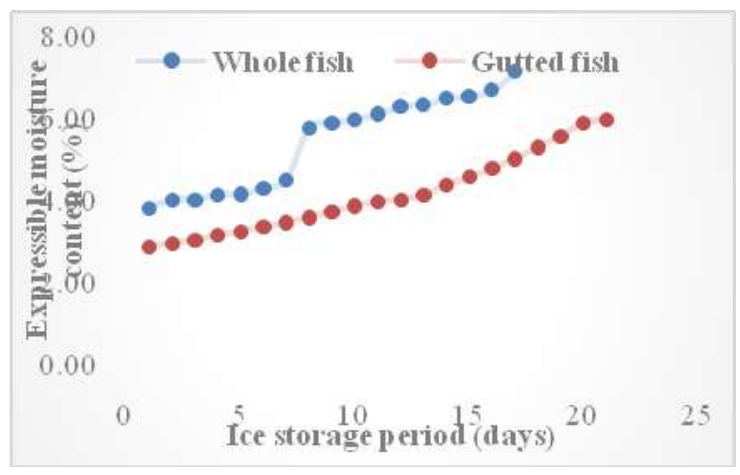

Fig.10 Changes in water holding capacity of whole and gutted pink perch during ice storage

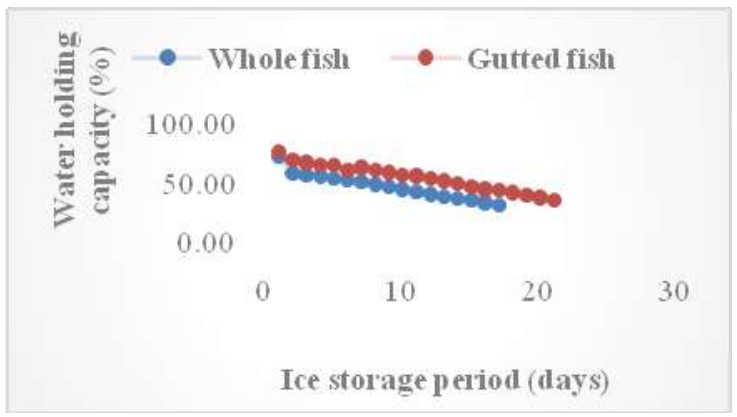

al., (2014) found similar observation in quality characteristics and shelf life of Sutchi cat fish (Pangasianodon hypophthalmus) steaks.

The effect of ice storage on the PS of whole and gutted pink perch is shown in Figure 5. As the storage time increased, the protein solubility decreased. The protein solubility (\%) decreased significantly from 61.99 on initial day to $10.70 \%$ and 66.10 on initial day to $14.15 \%$ of whole and gutted pink perch $(\mathrm{p}<0.05)$ at the end of $17^{\text {th }}$ and $21^{\text {st }}$ day of ice storage respectively. On initial days of storage, protein solubility in gutted fish decreased at faster rate, then it decreased slowly till fish spoiled. Reddy and Srikar (1993) attributed the decrease in PS to two factors: the loss of water soluble (sarcoplasmic) proteins in the melted ice and 
the denaturation of myofibrillar proteins. The reduction in solubility during ice storage is attributed to the behaviour of myofibrillar proteins as affected by ice storage. The process of association-dissociationdenaturation is the main contributing factor for reduction in solubility. Changes in protein solubility are a direct evidence of conformational changes of protein molecule. The solublization of myofibrillar proteins is the major factor affecting the functional properties of fish protein both during ice and frozen storage (Regenstein and Regenstein 1984). Sarma et al., (1999) have also reported a significant decrease in protein solubility of pink perch (Nemipterus japonicus) and oil sardine (Sardinella longiceps) meat during 16 and 20 days of ice storage respectively. Similar trends in protein solubility was observed by Reddy and Srikar (1993) on icestored Japanese threadfin bream (Nemipterus japonicus). Yathavamoorthi et al., (2012) also reported the decrease in protein solubility of Common carp surimi during ice storage.

The gel strength of whole and gutted pink perch mince during ice storage are shown in Figure 6. The decreasing gel strength was significantly different $(p<0.05)$ among the whole and gutted pink perch. The initial gel strength values for whole and gutted fish mince were 434 and 331 g.cm respectively, and the final gel strength values were 110 and 118 g.cm on $17^{\text {th }}$ and $21^{\text {st }}$ day respectively. On $13^{\text {th }}$ day, gel strength from whole fish decreased to 180 g.cm, while in gutted fish on day 15 it was 156 g.cm respectively. On day 17 , gel strength of surimi gel from whole fish was decreased to 110 g.cm, while that from gutted fish declined to 144 g.cm respectively. However, heading and gutting was effective in retaining the gel forming ability during iced storage. Continuous decreases in gel strength were observed when storage time increased $(\mathrm{P}<0.05)$. The rate of decreases in gel strength was higher in whole fish than headed/eviscerated fish. Kurokawa (1979) reported that gel strength of kamaboko made from lizardfish stored in ice for 3 days was less than $50 \%$ of that made from fresh fish. Yean (1993) also found a decrease in gel strength of surimi produced from threadfin bream stored in ice for more than 2 days. Therefore, storage time was a prime factor determining the gel quality of pink perch.

Benjakul et al., (2003) studied the postmortem changes in lizardfish during ice storage. They found that when the ice storage time increased, gel strength from surimi produced, from whole and headed/eviscerated fish, decreased up to $15^{\text {th }}$ day of storage $(p<0.05)$. In present study the gel strength of gutted fish had lower values as compared to whole fish, in contrast of Benjakul et al., (2003) study. But the values of whole fish decreased at faster level as compared to gutted fish. The heat coagulative sarcoplasmic protein adheres to myofibrillar protein when fish meat is heated. This phenomenon impedes the formation of gel in fish meat. This is considered to be one of the reasons why it is difficult to make a strong elastic gel form (Suzuki, 1981). The presence of endogenous heat-stable or heat-activated proteinases, which can degrade myosin and thus impair protein gelation. Equally important to surimi gelling ability is avoiding denaturation of myosin during surimi processing. These heatstable proteinases may potentially arise in muscle from a number of sources: microbial contamination, contamination of muscle by bits of organ tissues due to improper cleaning techniques, muscle reaction to or contamination by parasitic organisms, and abnormally high levels of such enzymes naturally occurring in the muscle. Denaturation of the protein prior to the time of surimi processing impairs the gel-forming ability of the proteins during subsequent heating of salted surimi paste (Park, 2005). 
Benjakul et al., (2003) attributed that heading and eviscerating were able to keep the transglutaminase activity, which functioned as a gel enhancer during the setting process. Transglutaminase in whole lizardfish was probably inactivated to a higher extent, than in beheaded/eviscerated samples. This was postulated to be caused by higher proteinase released and formaldehyde formed in whole samples during iced storage, leading to the inactivation of transglutaminase. The decrease in gel-forming ability of lizardfish surimi protein was concomitant with the increase in formaldehyde, TCA-soluble peptides and aamino acids, as well as the decrease in myosin heavy chain content. Myosin integrity is of paramount importance for gelation (An et al., 1996).

The whiteness of whole and gutted pink perch during ice storage are shown in Figure 7. Gel whiteness markedly decreased as storage time increased $(p<0.05)$. Higher decreasing rate of whiteness was found in whole fish as compared to gutted fish. The whiteness decreased significantly from 74.83 on initial day to 51.53 and 78.30 on initial day to 62.27 of whole and gutted pink perch during ice storage at the end of $17^{\text {th }}$ and $21^{\text {st }}$ day respectively. On $13^{\text {th }}$ and $15^{\text {th }}$ day of whole and gutted fish during ice storage whiteness values were 59.65 and 67.23 respectively. During iced storage, oxidation of pigments in fish muscle, particularly myoglobin or hemoglobin, occurred. These oxidised products possibly get bound tightly with muscle proteins, especially in the presence of formaldehyde and could not be removed by washing. As a consequence, surimi gel produced from fish kept for a longer time had lower whiteness. During extended storage, blood and liquid from internal organs in whole samples could penetrate through the muscle, especially when autolysis proceeded and caused a looser muscle structure. Benjakul et al., (2002) have also reported a significant decrease in whiteness of bigeye snapper, Priacanthus tayenus and $P$. macracanthus, stored in ice. Similar decrease in whiteness of ice-stored lizardfish was found by Chanarat et al., (2013).

Cook loss of mince samples from whole and gutted pink perch during ice storage are shown in Figure 8. A significant increase in CL was observed during ice storage $(\mathrm{P}<0.05)$. The $\mathrm{CL}$ increased initially from 16.50 to $23.33 \%$ and 16 to $28.67 \%$ at the end of $17^{\text {th }}$ and $21^{\text {st }}$ day of whole and gutted pink perch during ice storage respectively. A significant increase in cook loss may be attributed to poor water binding capacity of protein as a result of its denaturation during ice storage, as seen by the decreased PS during the same period. The post mortem breakdown of ATP and decreased $\mathrm{pH}$ are also responsible for drop in the hydration which might have resulted in increased cook loss (Hamm, 1960). Reddy and Srikar (1993) observed2.5 times more increased in the cook loss of pink perch meat during the 14days of ice storage. Sarma et al., (1999) also reported increase in cook loss during ice storage period of 20 days.

Expressible moisture content of surimi gel from whole and gutted pink perch increase with increasing storage time $(\mathrm{p}<0.05)$. Increase in expressible moisture content are shown in Figure 9. Whole fish exhibited higher expressible drip loss than gutted fish. The expressible drip loss increased significantly from 3.80 to $7.11 \%$ and 2.86 to $5.95 \%$ of whole and gutted pink perch during ice storage respectively. On $8^{\text {th }}$ day, the expressible moisture content of the whole fish increase in higher value. When fish are kept for a longer time, proteins get more degraded and loose their functionality, including gelation as well as water-holding capacity. As a result, less water was imbibed in the gel network, leading to higher drip (Benjakul et al., 2002). Chaijan et al., (2010) found 
changes in expressible drip loss by heating the gel at various temperature. Similar reports of changes in expressible moisture content was observed by Benjakul et al., (2002) in bigeye snapper, Priacanthus tayenus and $P$. macracanthus from whole fish and beheaded/eviscerated fish stored in ice.

WHC of surimi gel from whole and gutted pink perch decreased with increasing storage time (Fig. 10). Higher decreasing rate of WHC was found in whole fish as compared to gutted fish. The WHC decreased significantly from 71.28 to $31.17 \%$ and 75.16 to $35.16 \%$ of whole and gutted pink perch during ice storage respectively $(\mathrm{p}<0.05)$. Initially the WHC of gutted fish decreased at higher rate, then it is decreased slowly with increase in storage period.

Similar result was reported by Reddy and Srikar (1993). Bligh and Duclos-Rendell (1986) explained that the decrease in water holding capacity was due to the denaturation of proteins, as a result of which, the fish flesh proteins releases appreciable quantity of moisture.

The present study revealed that the shelf-life of whole and gutted pink perch stored in ice, as determined by the overall acceptability sensory scores data, was 13 and 15 days, respectively. Significant changes in the functional properties of fish proteins occurred during the storage period except in gel strength.

Initially, gel strength of whole fish was higher than gutted fish. At the end of the storage on $17^{\text {th }}$ and $21^{\text {st }}$ day, the gel strength of whole fish was lower as compared to gutted fish. A high positive correlation $(\mathrm{r}=0.94$ and $\mathrm{r}=$ 0.90) was obtained between texture and the gel strength of whole fish and gutted fish respectively during ice storage. Beyond 13 and 15 day, both whole and gutted samples were no longer acceptable according to sensory analysis.

\section{References}

Amitha, Raju, C. V., Lakshmisha, I. P., Pal J. and Singh R. R. (2018). Physiochemical, microbial and sensory changes in iced Threadfin bream (Nemipterus japonicus) stored in indigenously developed fish vending and display unit. International Journal of Chemical Studies, 6(2): 271-275.

An, H., Peters, M. Y., and Seymour, T. A. (1996). Roles of endogenous enzymes in surimi gelation. Trends in Food Science and Technology, 7: 321-327.

AOAC (2005). Official methods of analysis of the Association of Official Analytical Chemists, $18^{\text {th }}$ edition, Washington D.C. USA.

Ayyappan, S., Jena, J. K., Gopalakrishnan, A. and Pandey A. K. (2006). Handbook of Fisheries and Aquaculture. Indian council of agricultural research.

Ayyappan, S., Moza, U., Gopalakrishnan, A., Bharathiamma M., Jena, J. K. and Pandey, A.K. (2011). Handbook of Fisheries and Aquaculture. Indian council of agricultural research.

Beatty, S. A. and Gibbons, N. E. (1936). The measurement of spoilage in fish. Journal of biol. Bd. Can., 3: 77-91.

Benjakul, S., Visessanguan, W. and Tueksuban, J. (2003). Changes in physico-chemical properties and gelforming ability of lizardfish (Sauridatumbil) during post-mortem storage in ice. Food Chemistry, 80: 535-544.

Benjakul, S., Visessanguan, W., Riebroy, S., Ishizaki, S. and Tanaka, M. (2002). Gel forming properties of surimi produced from bigeye snapper, Priacanthus tayenus and $P$. macracanthus, stored in ice. Journal of 
the Science of Food and Agriculture, 82: 1442-1451.

Benjakul, S., Visessanguan, W., Tueksuban, J., and Tanaka, M. (2004). Effect of some protein additives on proteolysis and gel-forming ability of lizardfish (Sauridatumbil). Food Hydrocolloids, 18(3): 395-401.

Bligh, E. G. and Duclos-Rendell, R. (1986). Chemical and physical characteristics of lightly salted minced cod (Gadues morhua). Journal Food Sci., 51: 7678.

Borresen, T. (1980). New methods for determination of liquid holding capacity, salt water holding capacity and cook loss in fish muscle (in Norwegian). FTFI Report 663, Tromse, Norway.

Boyd, N. S., Wilson, N. D. and Edley, A. (1978) Proc. IPFC Symposium on fish utilization technology and marketing in IPFC Region, 18, 186.

Bramstedt, F. and Auerbach, M. (1965) in Fish as Food (Borgstrom, G. Ed.) vol. 1, p. 613, Academic Press Inc, New York.

Burgess, G. H. O., Cutting, C. L., Lovern, J. A. and waterman, J. J. (1965). Fish handling and processing. Her Majesty's Stationary Office, Edinburgh, Scotland.

Cakli, S., Kilinc, B., Cadun, A., Dincer, T. and Tolasa. S. (2007). Quality differences of whole ungutted sea bream (Sparus aurata) and sea bass (Dicentrarchus labrax) while stored in ice. Food Control, 18: 391-397.

Chaijan, M., Panpipat, W. and Benjakul, S. (2010). Physicochemical properties and gel-forming ability of surimi from three species of mackerel caught in Southern Thailand. Food Chemistry, 121: 85-92.

Chanarat, S. and Benjakul, S. (2013). Effect of formaldehyde on protein cross-linking and gel forming ability of surimi from lizardfish induced by microbial transglutaminase. Food Hydrocolloids, 30: 704-711.

Choi, Y. J. and Park, J. W. (2002). Acid-aided protein recovery from enzyme-rich Pacific Whiting. Journal of Food Science, 67(8): 2962-2967.

Connell, J. J. (1960). Changes in the ATPase activity and sulfhydryal groups of Cod flesh during frozen storage. Journal of the Science of Food and Agriculture, 11: 245-249.

Connell, J. J. (1975). Control of fish quality, Fishingnews (Book) Ltd., Farnham, Surrey, p. 179, UK. 4, 1-256.

Disney, J. C., Cameron, J. D., Hoffman, A. and Jones, N. R. (1971) in Fish Inspection and Quality Control, p. 71 (Kreuzer, R., Ed.) Fishing News Books Ltd., London.

Erkan, N. and Ozden, O. (2008). Quality assessment of whole and gutted sardines (Sardina pilchardus) stored in ice: International Journal of Food Science and Technology, 43: 15491559.

Eymard, S., Carcouët, E., Rochet, M-J., Dumay, J., Chopin, C. and Genot, C. (2005). Development of lipid oxidation during manufacturing of horse mackerel surimi. Journal of the Science of Food and Agriculture, 85: 1750- 1756.

Gram, L., and Huss, H. H. (1996). Microbial spoilage of fish and fish products. International Journal of Food Microbiology, 33: 121-137.

Hamm, R. (1960). Biochemistry of meat hydration. Adv Food Res., 10: 355463.

Harada, K. (1975). Studies on enzyme catalyzing the formation of formaldehyde and dimethylamine in tissues of fishes and shellfishs. Journal of Shimonoseki University of Fisheries, 
18: 296-302.

Hatae, K., Tamari, S., Miyanaga, K. and Matsumoto, J. (1985). Species difference and changes in the physical properties of fish muscle as freshness decreases. Bull. Japan Soc. Sci. Fish.,5, pp.1155-1161.

Huss, H. H. (1995). Quality and quality changes in fresh fish. FAO fisheries technical paper no. 348 .

Jaman, N., Hoque, M. S., Chakraborty, S. C., Hoq, M. E. and Seal, H. P. (2015). Determination of formaldehyde content by spectrophotometric method in some fresh water and marine fishes of Bangladesh. International Journal of Fisheries and Aquatic Studies, 2(6): 94-98.

Kumar, P. S., Mohite, S. A., Naik, S. D. \&Mohite, A. S. (2011). Length weight relationship in Nemipterus japonicus of Ratnagiri coast along Maharashtra. Indian Journal of Applied and Pure Biology, 26(1): 79-84.

Kurokawa, T. (1979). Kamaboko-forming ability of frozen and ice stored lizard fish. Bulletin of the Japanese Society of Scientific Fisheries, 45, 1551-1555.

Lanier, T. C. (1986). Functional properties of surimi. Food Technology, 40(3), 107114.

Lanier, T. C. (2000). Surimi gelation chemistry. In J. W. Park (Ed.), Surimi and Surimiseafood (pp.237-265). New York, USA: Marcel Dekker.

Leelapongwattana, K., Benjakul, S., Visessanguan, W., and Howell, N. K. (2005). Physicochemical and biochemical changes in whole lizardfish (Saurida micropectoralis) muscles and fillets during frozen storage. Journal of Food Biochemistry, 29(5): 547-569.

Manju, S., Jose, L., Gopal, T. K. S., Ravisankar, C. N. and Lalitha, K. V. (2007). Effect of sodium acetate dip treatment and vacuum-packaging on chemical, microbiological, textural and sensory changes of pearl spot (Etroplus suratensis) during chilled storage. Food Chem., 102: 27-35.

Mehta, N. K. and Shamasundar, B. A. (2015) Changes in chemical and sensory properties of freshwater fish (Indian Major Carps) during ice storage. Prog. Agric., 15(2): 202-207.

Nopianti, R., Huda, N., Fazilah, A., Ismail, N. and Easa, A. M. (2012). Effect of different type of low sweetness sugar on physiochemical properties of threadfin bream surimi (Nemipterus spp.) during frozen storage. International Food Research Journal, 19 (3): 1011-1021.

Ofstad, R., Kidman, S., Mykle, B. R., Olsen R. L. and Hermansson A. M.(1995). Lipid holding capacity and structural changes in comminuted salmon (Salmon salar) muscles influenced by $\mathrm{pH}$, salt and temperature. Lebeensmittel-Wissenschaftand Technologie, 28(3): 329-339.

Papadopoulos. V., Chouliara, I., Badeka, A., Savvaidis, I. N. and Kontominas, M. G. (2003). Effect of gutting on microbiological, chemical, and sensory properties of aquacultured sea bass (Dicentrarchus labrax) stored in ice. Food Microbiology, 20: 411-420.

Park, J. W. (2005). Surimi and surimi seafood. Second edition. pp. 230-231.

Rawdkuen, S., Sai-Ut, S., Khamsorn, S., Chaijan, M. and Benjakul, S. (2009). Biochemical and gelling properties of tilapia surimi and protein recovered using an acid-alkaline process. Journal of food chemistry, 112 (1): 112-119.

Reddy, G. V. and Srikar, L. N. (1991a). Effect of ice storage on protein and related changes in pink perch (Nemipterus japonicus). J. Food Sci. Technol. 28: 101-104. 
Reddy, V. G and Srikar LN, (1993). Functional properties of ice stored Japanese threadfin bream (Nemipterus japonicus). Asian Fisheries Sci., 6:3137.

Regenstein J. M. and Regenstein C. E. (1984). Food protein chemistry: an introduction for food scientists. Academic press, New York.

Sarma, J., Srikar, L. N. and Reddy, G. (1999). Effect of ice storage on the functional properties of pink perch and oil sardine meat: Journal of the Science of Food and Agriculture, 79: 169-172.

Sasajima, M. (1973). Studies on the psychrotelerant bacteria in fish and shellfish. IV. Relation between the number of trimethylamine oxidereducing psychrotrophic bacteria and their activity. Bulletin of the Japanese Society of Scientific Fisheries, 39, 511-518.

Sasajima, M. (1975). Studies on psychrotolerant bacteria in fish and shellfish. V. The growth or viability of trimethylamine oxide-reducing psychrotrophic bacteria and their activity at subzero temperatures. Bulletin of the Japanese Society of Scientific Fisheries, 40, 630-635.

Suzuki, T. (1981). Fish and krill protein processing technology. pp. 12.

Tina, N., Nurul, H. and Ruzita, A. (2010). Review Article Surimi-like material: challenges and prospects. International Food Research Journal, 17: 509-517.

Viji, P., Tanuja, S., George, N., Zynudheen, A. A. andLalitha, K. V. (2014). Quality characteristics and shelf life of sutchi cat fish (Pangasianodon hypophthalmus) steaks during refrigerated storage. Intl. J. Agric. Food Sci. Technol., 5(2): 105-116.

Yathavamoorthi, R., Sankar, T. V. and Ravishankar, C. N. (2012). Effect of ice storage on the characteristics of Common carp surimi. Fishery Technology, 49: 38-44.

Yean, Y. S. (1993). The quality of surimi made from threadfin bream stored on ice for different periods. International Journal of Food Science and Technology, 28, 343-346.

\section{How to cite this article:}

Sarve, N. S., S. B. Patange, S. T. Sharangdher, J. M. Koliand and Kulkarni, G. N. 2019. Comparative Study on Functional Characteristics of Whole and Gutted Pink Perch (Nemipterus japonicus) During Ice Storage. Int.J.Curr.Microbiol.App.Sci. 8(10): 2537-2549. doi: https://doi.org/10.20546/ijcmas.2019.810.294 